\title{
Culture Shock: The Organization of Civil Society as Meaningful Actor
}

\author{
Alena Řiháková ${ }^{1}$ Pavel Filo² \\ ${ }^{1}$ Department of Anthropology, Faculty of Science, Masaryk University, Vinařská 5, 60300 Brno \\ ${ }^{2}$ Department of advisory services and multicultural activities in Diocesan Charity Brno, tř. Kpt. Jaroše 9, 60200 Brno
}

\section{KULTURNÍ ŠOK: ORGANIZACE OBČANSKÉ SPOLEČNOSTI JAKO VÝZNAMNÝ AKTÉR}

ABSTRAKT Vzájemné kontakty kultur vytvářejí prostor pro řadu zkušeností. Jednou z nich je i kulturní šok, který pramení z početných stresorů. Ty se objevují po kontaktu s jinou kulturou. Kulturní šok je reakcí na vystavení neznámým a neočekávaným okolnostem a reprezentuje psychologický dopad adaptace na novou kulturu. Existují však způsoby zvládání kulturního šoku a můžeme identifikovat pozitivní elementy, které ovlivňují tento fenomén. Tato práce předkládá, jak organizace občanské společnosti může ovlivnit zkušenost s kulturním šokem. In media res článek analyzuje aktivity Diecézní Charity Brno ve vztahu ke kulturnímu šoku. Uvádíme, že organizace občanské společnosti přispívají k překonání kulturního šoku.

KLÍČOVÁ SLOVA akulturace; kultura; kulturní šok; organizace občanské společnosti; sociální sítě

ABSTRACT Reciprocal contacts of cultures open space for a lot of experience. One of them is culture shock. It results from numerous stressors. They occur due to contact with a different culture. Culture shock happens because of encountering unfamiliar and unexpected circumstances and represents a psychological impact of adaptation to a new culture. However there are ways for managing culture shock. In other worlds, we can identify positive elements influencing this phenomenon. This paper poses how organization of civil society can affect experience of culture shock. In media res this article analyses activities of Diocesan Charity Brno in relation to culture shock. We claim that organizations of civil society contribute to bridging culture shock.

KEY WORDS acculturation; culture; culture shock; organization of civil society; social networks

\section{INTRODUCTION}

In recent decades, people of the world became closer because of technological progress in communication and transportation. The globalization and migration increase need for understanding culture variability and managing intercultural relationships. In particular facing new culture reveals culture shock. Various degrees of culture shock appear because of unfamiliar cultural or subculture settings. It has multifaceted links in multicultural societies and global dimension. So the need of managing culture shock increases in our society (Merta et al. 1988; Winkelman 1994).

Culture shock is more intuitive concept with a large descriptive literature. It hasn't own diagnostic criteria. Yet there is an attempt to measure culture shock and state boundaries of the concept (Mumford 1998). Culture shock is in consideration of many sciences, such as psychology, psychoanalysis, psychiatry, sociology and anthropology. They observe emotional, behavioral, psychical, cognitive and physiological impact of culture shock on person. In passing the anthropologists face culture shock in their fieldwork experience and ethnographic researches (Irwin 2007). However, not enough awareness is given to clarify position of the organizations of civil society in managing and affecting this phenomenon.

The purpose of this project is describing the impact of organization of civil society on culture shock and the solutions, which organization offers. Organizations of civil society are meaningful actors in the process of a migration. Their target 
groups are mainly refugees, applicants for international protection and foreigners in need. So their clients experience culture shock. We pose the organizations of civil society as a positive element in managing culture shock. Therefore we focus on the activities of Diocesan Charity Brno, CELZUS-Services for foreigners as a representative of civil society. The origin of idea of civil society is in European intellectual discourses. The concept of civil society has been formed in light of social, cultural and historical contexts since European Enlightenment. Now, we register return of civil society in Czech Republic after the fall of the old regime. So, we satisfy the need in mapping civil society in our society.

\section{CULTURE SHOCK}

A contact with a different cultures or cultural settings leads to culture shock. It refers to the transition period. Berry et al (1992) distinguish between the consequences of culture shock and prefer the term "acculturative stress" than "culture shock" in order to highlight the stress and its psychological dimension. Acculturative stress means a qualitative change of life when man is exposed to a new culture. Intercultural relations produce stressors having impact on individual in many ways. Culture shock hasn't only negative implication but also it means positive development. The main advantage is learning experience, increase of intercultural understanding, enhancement of self-efficiency and individual development (Furnham - Bochner 1986; Milstein 2005).

Culture shock is multidimensional process depending on variety of factors. They influence individual's perception of culture shock. Furnham and Bochner (1986) identified six classes of predictor variables: Control of conditions for initiating contact with the host culture; intrapersonal factors (such as age, language skills, ambiguity tolerance appearance etc.); biological factors in relations to physical conditions and general state of health; interpersonal factors (such as clearly defined role); characteristics of the host culture and geopolitical conditions in the host culture. So these factors determine reactions of specific persons (Berry et al 1992; Pedersen 1995). A number of individuals face different culture and culture settings. Researchers analyze these groups of individuals. These are immigrant groups (for example refugees) (Fozdar 2009), businessman traveling overseas (Howard 1974; Smith 2008), global managers (Feldman - Thompson 1992), populations undergoing massive technological and social change (Toffler 1970), staff and public in hospitals and institutions etc. Generally members of multicultural societies display culture shock frequently. Thus the target groups of the organizations of civil society dealing with immigrants undergo culture shock as well.

The experts dealing with culture shock suggest that various stages of this phenomenon can be experienced. Lysgaard (1955) developed the U-curve hypothesis in 1955. He explained the adjustment model of international students in a host culture. Consequently some of them have accounted re-entry phase. It extends the U-curve to the W-curve construct. In short the adjustment and the adaptation can repeat while returning (Bochner et al. 1980; Gulahorn - Gulahorn 1963). Oberg (1954) distinguished seven stages of the adjustment: incubation stage; crises resulting from common daily activity; understanding the host culture; objective screening of the host culture; reentry; reverse culture shock and readjustment to home culture (Pedersen 1995). Accordingly experts have arranged various degrees of culture shock (Adler 1975, according Furnaham - Bochner 1986; Dodd 1995; Oberg 1954; Pedersen 1995).

In the same way scientists have created list of symptoms and signs of culture shock. For example Oberg (1954, p. 2) published these symptoms: "excessive washing of the hands; excessive concern over drinking water, food, dishes, and bedding; fear of physical contact with attendants or servants; the absentminded, far-away stare (sometimes called the tropical stare); a feeling of helplessness and a desire for dependence on long-term residents of one's own nationality; fits of anger over delays and other minor frustrations; delay and outright refusal to learn the language of the host country; excessive fear of being cheated, robbed, or injured; great concern over minor pains and eruptions of the skin; and finally, that terrible longing to be back home, to be able to have a good cup of coffee and a piece of apple pie, to walk into that corner drugstore, to visit one's relatives, and, in general, to talk to people who really make sense." Kanaiaupuni (1980) poses clinical cases of culture shock on Guam. In brief culture shock results in psychological and physiological reactions. Psychological responses take emotional, cognitive, interpersonal and social effect (Winkelman 1994). Emotional state includes anxiety, depression and hostility (Pedersen 1995). Feelings of people can lead to rejecting the nationals of the country during the most problematic stage of culture shock. Therefore they could behave ethnocentrically. This could result in conflicts and problems in relationships (Dodd 1995).

\section{MANAGING CULTURE SHOCK}

It is widely accepted, that there are approaches to handle culture shock. Winkelman (2003) suggests that managing culture shock indicates to acculturation. It means that individual must effectively understand to new culture. It involves culturally relativistic approach and tolerance. Taft (1977) states, that managing culture shock and engagement in the new society are particular instance of human adaptation (Taft 1977; Winkelman 1994). So the professionals have created ways for managing culture shock. Two stages of solution culture shock can be identified. They could be divided into pre-departure and stage during the experience (Xia 2009).

We know these steps for managing culture shock:

Pre-departure preparation

Preparation and collecting information about new culture is the first and basic recommendation in pre-departure preparation (Moran et al. 2007). This step helps to orientate in new 
society. Appropriate way to reduce psychological stress is to understand the stages of culture shock (e. g. danger signs and signals) and becoming familiar with new culture. It includes moving with realistic expectations about new cultures and awareness of own limitations. However the preparation only decreases influence of culture shock (Xia 2009, Zapf 1991).

This preparation has advantages for these people, who are voluntary migrants and have resources of such information. For instance profit organizations offer cross-cultural trainings for employees traveling abroad (Black - Mendenhall 1990). However this way is limited for refugees and other groups of non-voluntary immigrants. There seem to be few opportunities for organizations of civil society to improve this situation. Usually these organizations don't have an effect on their clients in the country of origin.

Self-confidence, optimism and accepting new culture Xiu (2009) poses, that people with high self-efficacy and optimism are more effective in overcoming obstacles. Open mind and the respect to new culture and its settings create appropriate surrounding to manage culture shock.

Intercultural effectiveness and ability to solve conflict

The regulation of culture shock would be easier, if one effectively used problem-solving approach. Harris and Moran (1987, according Winkelman 1994) describe this process as describing, analyzing and identifying the problem from both cultures perspectives.

Personal, social relations and social support

As it was mentioned above, culture shock may cause difficulties in relationships. On the other hand interpersonal relationships have supportive function (Furnham - Bochner 1986, Scott 2005). Pantelidou and Craig (2006) documented social support as an important factor associated with the degree of culture shock among students. Relationships can be divided into relationship with family and friends and secondary relationships. Organization support is useful tool as well. It represents social groups, sport teams, artistic and theatrical productions etc. Further groupwork approach is the preferred method with individuals experiencing culture shock. Especially activities with nonverbal communication channels (dances, festivals, sport events) help to enlarge social relations (Winkelman 1994, Zapf 1991). In particular modern tools of communication (social networks, internet, mobile phones etc.) produce chance to reach social support across planet (Smith 2005; Xiu 2009).

\section{Basic needs}

The satisfaction of basic needs makes individual free to focus on cultural adaptation. Basic needs can be grouped into physiological needs and safety. It represents well-being-food, security, housing and health. If one meets these requirements, it opens the door to concentrate on social relations and personal development (Winkelman 1994).

\section{Maintenance and reparative behaviors}

Both maintenance behaviors and reparative behaviors play an important role in managing stress and culture shock. Maintenance behaviors may represent the contact with own culture and maintenance own culture sense, such as language, food, interactions with home, jobs that support one's sense of self. Reparative behavior restores the qualities of life in the new culture (Winkelman 1994).

\section{Communication competences}

Mastery of new language is very important to be understood and generally for the adjustment process. On the one hand social networks in host culture improve communication competences, on the other hand improvement in new language opens opportunities for new relationships (Scott 2005; Smith 2005; Zapf 1991).

Meeting new cultural and social interaction rules

Understanding cultural and social rules helps to adjust in the new society. Not only language styles, but also nonverbal communication, paralinguistic conventions, emotional communication, interpersonal behavior patterns and rules are useful for existence in new society (Winkelman 1994).

\section{ACTIVITIES OF DIOCESAN CHARITY BRNO}

We submit main recommendations about culture shock in context of activities and services of Diocesan Charity Brno, CELZUS - Services for foreigners. Organizations of civil society reflect needs of individuals and societies. They fill gap between the state and the profit sector and respond to outstanding needs in heterogeneous societies (Rektořík 2007). These organizations are significant actor in the process of a migration and intercultural communication. Thus their clients experience intercultural relationships and culture shock. While it is true to say that they don't provide services and activities for whole spectrum of immigrants and foreigners. Their main target groups are refugees, applicants for international protection and foreigners in need.

Caritas CR run a network of specialized counseling centers, one of them is within Diocesan Charity Brno, CELZUS - Services for foreigners. Diocesan Charity Brno has been providing service for foreigners since 1994. Caritas CR coordinator realizes methodical coordination of migration activities within Caritas CR. So Diocesan Charity Brno has lot of experience in this phenomenon. CELZUS - Services for foreigners is department of this organization and provides for instance: social and basic law advices; mediating entry to social networks; obtaining accommodations; material and social services; counseling social security; assistances by dealing with institution and offices; services in area of labor market.

Firstly we focus on material and social services, including help with obtaining accommodations. This aid is provided to clients in cases of their demonstrable social and financial need. It includes for example food, clothing, footwear, bedclothes, financial contribution for extemporary accommodation and tickets. These basic needs construct position for easier cultural adaptation (Charita ČR 2010).

In particular we pose two projects in order to analyze effect of the organization on culture shock. The first project was realized since 2008 to 2009. Next project represents project 
intentions and vision, which is going to be reached in years 2011-2012. These missions are going to support integration of foreigners, reinforce socio-cultural orientation and social adaptation and create positive vein to managing culture shock. In the same way these projects affect host society. They create space for dialog between cultures and inform public.

\section{Project 1: Integration and creative activities of refugee children}

The outputs of the project were: A/ Creative hobby group for children at residential centre Zastávka u Brna and then at Multicultural centre of Diocesan Charity Brno; B/ The children had opportunity to visit places outside residential centre, such as the cinema, museum, swimming pool, theme park, and play games; $\mathrm{C} /$ Learning programs for children attending primary schools. There were exploiting knowledge from creative therapy, art therapy and drama therapy in creative hobby group. It has benefit in psychotherapy, breaks communication barriers and has positive influence on self-esteem. So the kids had opportunity to fill his free time and to pick up relationships (Barksdale 2003; Maat 1997; Rappaport 2010; Rosseau 2005; Westrich 1994). The kids visited places outside residential centre, so they cognized new culture.

Target group of this project were children, especially refugees and applicants for international protection, foreign children and children from major society. The main reaction among children of host society was in age of 13-15. These children reflected negative experience of exclusion, isolation and were able to realize prejudices. The evaluation of this project reveals enhancement of communication skills, personal development, and progressive improvement of relationships within collective and social adaptability.

The project was financially supported by public collection organized jointly by the Czech Television (ČT) and Civil Society Development Foundation (NROS) (Diecézní charita Brno 2010; Diecézní charita Brno 2009).

The positive stimulus on managing culture shock has especially development of communication skills, improvement of relationships and cognition new culture.

\section{Project 2: No Barriers}

Applicants for international protection are one of the most endangered groups of immigrants. This group and people, who reach their application, usually don't have appropriate language skills. They experience not only culture shock, but also posttraumatic stress disorder. The mission solves and manages problems, such as culture shock, psychical difficulties, language and social barriers. It helps to orientate in new cultural environment.

Variability of cultures (such as norms, traditions, customs etc.) and languages barriers results in misunderstanding between clients and medical care. Indeed there is lack of regular monitoring of health of target groups. Actually these target groups don't practice active preventive approach to their well-being.
The project lends a hand in area of medical care. Target groups of this project experience refusal at medical institutions because of language barriers. So the organization is going to cooperate with medical institutions to create communication cards. They are going to be used in order to break language barriers. The project is going to assist with psychological care. It is going to establish psychotherapeutically groups on the basis of language mood. It should break language barriers, which cause inadequate psychological care. Information campaign about active approach to well-being is going to be realized within this mission and is going to translate in Russian, Vietnamese, Mongolian and English.

Co-financing proposal was given to European Refugee Fund in October 2010.

The project represents positive vein managing culture shock in following points: Language barriers and state of health are predictor variables influencing individual's perception of culture shock. Physical well-being is basic need, which enables to concentrate on social relation and personal development. Psychological care helps to manage culture shock. It helps to solve problems and psychological aspects of culture shock. In conclusion we can state, that the organization positively affects its clients in many ways. One of them is creating appropriate conditions for managing culture shock and direct help with well-being and managing culture shock.

\section{CONCLUSION}

In era of globalized world and migration, understanding culture shock becomes more useful. People from various cultures experience culture shock and there are ways for managing culture shock. These are among others: Pre-departure preparation; self-confidence, optimism and accepting new culture; intercultural effectiveness and ability to solve conflict; personal, social relations and social support; basic needs; communication competences; maintenance and reparative behaviors and meeting new cultural and social interaction rules. Civil society arises in democratic societies and creates conditions for understanding and confident relationships between cultures. We propose example of activities which declare that organization of civil society help their clients to manage culture shock. So organizations of civil society play an important role in managing culture shock and prevent difficulties resulting from experience of culture shock.

\section{REFERENCES}

Adler, P. S. (1975): The Transitional Experience: An Alternative View of Culture Shock. Journal of Humanistic Psychology, 15 (4), 13-23. According: Furnham, A. - Bochner, S. (1986): Culture Shock: Psychological Reactions to Unfamiliar Environments. London: Methuen.

Barksdale, A. L. (2003): Music Therapy and Leisure for Persons with Disabilities. Sagamore Publishing. SPORTDiscus with Full Text. EBSCO.

Berry, J. W. - Poortinga, Y. H. - Segall, M. H. - Dasen, P. R. (1992): CrossCultural Psychology. Research and Application. Cambridge: Cambridge University Press. 
Black, J. S. - Mendenhall, M. (1990): Cross-Cultural Training Effectiveness: A Review and a Theoretical Framework for Future Research. Academy of Management Review, 15 (1), 113-136.

Bochner, S. - Lin, A. - McLeod, B. (1980): Anticipated Role Conflict of Returning Overseas Students. Journal of Social Psychology, 110 (2), 265-272.

Diecézní charita Brno (2010): Výroční zpráva 2009.

Diecézní charita Brno (2009): Výroční zpráva 2008.

Dodd, C. H. (1995): Dynamics of Intercultural Communication. Madison: Brown\& Benchmark.

Feldman, D. C. - Tompson, H. B. (1992): Entry Shock, Culture Shock: Socializing the New Breed of Global Managers. Human Resource Management, 31 (4), 345-362.

Fozdar, F. (2009): 'The Golden Country': Ex-Yugoslav and African Refugee Experiences of Settlement and 'Depression'. Journal of Ethnic and Migration Studies, 35 (8), 1335-1352.

Furnham, A. - Bochner, S. (1986): Culture Shock: Psychological Reactions to Unfamiliar Environments. London: Methuen.

Gullahorn, J. - Gullahorn, J. (1963): An Extension of the U-Curve Hypothesis. Journal of Social Issues, 19 (3), 33-47.

Harris, P. - Moran, R. (1987): Managing Cultural Differences. Houston,TX: Gulf. According: Winkelman, M. (1994): Cultural Shock and Adaptation. Journal of Counseling and Development, 73 (2), 121-126.

Howard, C. G. (1974): The Returning Overseas Executive: Cultural Shock in Reverse. Human Resource Management, 13 (2), 22-26.

Charita ČR (2010): Pomoc cizincưm v nouzi na území ČR. Praha: Charita ČR.

Irwin, R. (2007): Culture Shock: Negotiating Feelings in the Field. Anthropology Matters, 9 (1).

Kanaiaupuni, D. (1980): Cultural Shock as Seen in the Clinical Setting. Communication, 9 (1), 52-59.

Lysgaard, S. (1955): Adjustment in a Foreign Society: Norwegian Fulbright Grantees Visiting the United States. International Social Science Bulletin, 7 (1), 45-51. According: Pedersen, P. (1995): The Five Stages of Culture Shock. Westport: Greenwood Press.

Maat, M. B. (1997): A Group Art Therapy Experience for Immigrant Adolescents. American Journal of Art Therapy, 36 (1), 11-19.

Merta, R. - Stringham, E. - Ponterotto, J. (1988): Stimulating Culture Shock in Counselor Trainees: An Experiential Exercise for Cross-Cultural Training. Journal of Counseling and Development, 66, 242-245.

Milstein, T. (2005): Transformation Abroad: Sojourning and The Perceived Enhancement of Self-efficacy. International Journal of Intercultural Relations, 9, 217-238.

Moran, R. T. - Harris, P. R. - Moran, S. V. (2007): Managing Cultural Differences. Burlington: A Butterworth-Heinemann Title.

Mumford, D. B. (1998): The Measurement of Culture Shock. Social Psychiatry \& Psychiatric Epidemiology, 33 (4), 149-154.

Oberg, K. (1954): Culture Shock (online), presented to the Women's Club of Rio de Janeiro. http://www.smcm.edu/Academics/internationaled/Pdf/ cultureshockarticle.pdf.

Pantelidou, S. - Craig, T. K. J. (2006): Culture Shock and Social Support. Social Psychiatry \& Psychiatric Epidemiology, 41 (10), 777-781.

Pedersen, P. (1995): The Five Stages of Culture Shock. Westport: Greenwood Press.

Rappaport, L. (2010): Focusing-Oriented Art Therapy: Working with Trauma. Person-Centered \& Experiential Psychotherapies, 9 (2), 128-142.
Rektořík, J. (2007): Organizace neziskového sektoru. Praha: EKOPRESS, s. r. o.

Rousseau, C. - Drapeau, A. - Lacroix, L. - Bagilishya, D. - Heusch, N. (2005): Evaluation of a Classroom Program of Creative Expression Workshops for Refugee and Immigrant Children. Journal of Child Psychology and Psychiatry, 46 (2), 180-185.

Scott, J. T. (2005): Chapter 16: Managing in Different Cultures. Haworth Press, Inc. Business Source Complete, 121-128.

Smith, D. (2008): Pulling the Plug on Culture Shock: A Seven Step Plan for Managing Travel Anxiety. Journal of Global Business Issues, 2 (1), 41-46.

Taft, R. (1977): Coping with Unfamiliar Cultures. In Warren, N. (Ed.). Studies in Cross-Cultural Psychology, 1. New York: Random. pp. 125-153. According: Winkelman, M. (1994): Cultural Shock and Adaptation. Journal of Counseling and Development, 73 (2), 121-126.

Toffler, A. (1970): Future Shock (online). http://worldview.cceia.org/archive/ worldview/1972/01/1986.html/_res/id=sa_File1/v15_i001_a 13.pdf.

Westrich, C. A. (1994): Art Therapy with Culturally Different Clients. Art Therapy: Journal of the American Art Therapy Association, 11(3), 187190.

Winkelman, M. (1994): Cultural Shock and Adaptation. Journal of Counseling and Development, 73 (2), 121-126.

Xia, J. (2009): Analysis of Impact of Culture Shock on Individual Psychology. International Journal of Psychological Studies, 1 (2), 97-101.

Zapf, M. K. (1991): Cross-Cultural Transitions and Wellness: Dealing with Culture Shock. International Journal for the Advancement of Counselling, $14,105-119$.

\section{AUTHORS}

Alena Řiháková was born on 1st May 1983. She has master degree in Anthropology and Bachelor degree in Public Economy and Administration. She is a post-graduate student in Anthropology and a lecturer of Anthropology of Civil Society at Department of Anthropology, Faculty of Science, Masaryk University. She is interested in Anthropology of Civil Society and Anthropology of Economy.

Contact: Alena Řiháková, Vinařská 5, 60300 Brno, e-mail: alkari@centrum.cz.

Pavel Filo was born on 18th March 1975. He has master degree in Arts in Science of religions, Latin language a literature. He worked as a project coordinator of Department for migration in area of migration in Diocesan Charity Brno since 2002 to 2008. He has worked as a project coordinator of Department of advisory services and multicultural activities in Diocesan Charity since 2009.

Contact: Pavel Filo, tř. Kpt. Jaroše 9, 60200 Brno, e-mail: migrace.dchbrno@caritas.cz. 